\title{
Evolutionary Perspectives on Violence, Homicide, and War
}

James R. Liddle, Todd K. Shackelford, and Viviana A. Weekes-Shackelford

\begin{abstract}
We review and discuss the evolutionary psychological literature on violence, homicide, and war in humans and nonhumans, and in doing so we argue that an evolutionary perspective can substantially enhance our understanding of these behaviors. We provide a brief primer on evolutionary psychology, describing basic tenets of the field. The theories of sexual selection and parental investment are explained and subsequently used to highlight the evolutionary logic underlying the use of violence by humans and other animals. Our examination of violent behavior begins with a focus on nonhuman animals, reviewing the different contexts in which violence occurs and discussing how an evolutionary perspective can explain why it occurs in these contexts. We then examine violence in humans and illustrate the similarities and differences between human and nonhuman violence. Finally, we summarize what an evolutionary perspective can offer in terms of understanding violence, homicide, and war, and we discuss directions for future research.
\end{abstract}

Key Words: evolution, evolutionary psychology, sexual selection, parental investment, aggression, violence, homicide, war

\section{Introduction}

Violence, defined by the World Health Organization as "the intentional use of physical force or power, threatened or actual, against oneself, another person, or against a group or community, that either results in or has a high likelihood of resulting in injury, death, psychological harm, maldevelopment or deprivation" (Dahlberg \& Krug, 2002, p. 5), is a ubiquitous characteristic of human societies, both past and present. For example, although crime rates in the United States have decreased in recent years, there were 13,636 homicides and 1,318,398 violent crimes reported in 2009 (U. S. Department of Justice, 2010). Lifetime prevalence estimates of the rape of women in Western samples reach as high as $13 \%$, which may actually be an underestimate (see McKibbin \& Shackelford, 2011), and between
$10 \%$ and $26 \%$ of women experience rape in marriage (Goetz, Shackelford, Starratt, \& McKibbin, 2008). The suicide rate in the United States stands at roughly 11 per 100,000 , which is lower than the global average of 14.5 per 100,000 (Brown \& Brown, Chapter 9, this volume) but still translates into approximately 34,100 deaths per year. Around the world, roughly 87,500,000 people have died as a result of wars in the 20th century, with $54,000,000$ of these being civilian deaths (Smith, 2007, p. 18). Among hunter-gatherer tribes, an average of $13 \%$ (based on archaeological data) to $15 \%$ (based on ethnographic data; Bowles, 2006) of men die due to warfare, and roughly $20 \%-30 \%$ of men die from tribal violence among the Yanomamö (Chagnon, 1988). This collection of statistics is by no means complete; it merely scratches the surface

This chapter is based on Liddle, Shackelford, and Weekes-Shackelford (in press). 
of the quantity and quality of violence perpetrated by humans.

How can we explain these phenomena? Although some violent episodes can be attributed to substance abuse, mental illnesses or disorders, and so forth, the majority of violent behavior in our species, as well as in other species, cannot be dismissed as an aberration. Violent behavior, including homicide and war, requires a deeper explanation, which can be provided by adopting an evolutionary perspective.

\section{An Evolutionary Psychological Perspective}

In the distant future I see open fields for more important researches. Psychology will be based on a new foundation, that of the necessary acquirement of each mental power and capacity by gradation. Light will be thrown on the origin of man and his history.

—Charles Darwin, 1859, p. 488

Evolutionary psychology represents the "new foundation" of psychology that Darwin envisioned, in which the evolution of the mind is not only acknowledged, but the theory of evolution is applied to the study of the mind. Evolutionary psychology is not a subdiscipline of psychology, but instead it represents a unifying approach to psychology in which the theory of evolution can be-and has been to varying degrees—applied to all psychological subdisciplines (see Buss, 2011). For example, much progress has been made in incorporating evolutionary theory into the subdisciplines of social psychology (Kenrick, Neuberg, \& Cialdini, 2009), developmental psychology (Ellis \& Bjorklund, 2005), cognitive psychology (Pinker, 2009), abnormal psychology (Wakefield, 1992), and personality psychology (Buss, 2009).

Specifically, evolutionary psychologists posit that the human brain is composed of a large number of domain-specific information-processing mechanisms (i.e., evolved psychological mechanisms; Buss, 2011) that were selected over deep evolutionary history in response to the specific and recurrent adaptive problems faced by our ancestors, such as finding food and shelter, avoiding predators, finding a mate, and protecting and providing for one's children-in short, problems related to survival and reproduction (Tooby \& Cosmides, 2005). The existence and role of domain-general mechanisms (e.g., fluid intelligence) are currently debated, but evolutionary psychologists maintain that the brain is predominantly comprised of domain-specific mechanisms.

Evolved psychological mechanisms function by registering specific types of input (e.g., environmental stimuli, physiological activity, output from other psychological mechanisms), processing this information, and generating a specific output (i.e., physiological activity, information for other psychological mechanisms, or manifest behavior; Buss, 2011). As a result of this process, evolved psychological mechanisms may generate maladaptive behavior in contemporary societies due to novel inputs. For example, a mechanism that generates a preference for fatty foods is likely to have been adaptive for much of our evolutionary history due to the scarcity of food in general, but this mechanism can result in serious health problems in contemporary societies where fatty foods are cheap and plentiful. Similarly, humans often experience fear in response to stimuli that are likely to have been potent threats throughout our evolutionary history (e.g., snakes and spiders), even if they no longer represent realistic threats in contemporary environments. However, stimuli that do represent threats in such environments (e.g., automobiles, electrical outlets, and other novel sources of injury or death) rarely elicit similar levels of fear because they have not existed long enough for psychological mechanisms to be selected for in response to these threats (Öhman \& Mineka, 2001).

Given the view of the mind outlined earlier, evolutionary psychologists proceed to generate hypotheses about what types of psychological mechanisms exist based on defensible assumptions about the selection pressures faced throughout human evolutionary history. These hypotheses include predictions regarding the outputs that are expected to be generated in contemporary environments (i.e., environments that provide novel inputs that did not exist when these mechanisms evolved). As we will see later in this chapter, the approach described earlier has significantly expanded our understanding of violence, homicide, and war.

However, before one can fully appreciate the contribution that an evolutionary perspective has made toward understanding these behaviors, it is important to note that evolutionary psychologists do not contend that such behaviors are inevitable. Despite the increased incorporation of an evolutionary perspective into mainstream psychology over recent years (see Cornwell, Palmer, Guinther, \& Davis, 2005), evolutionary psychology continues to be met with criticisms that largely stem from misconceptions of the field, such as the idea that evolutionary psychology implies genetic determinism (e.g., Coyne, 2009). Since there have already been several rebuttals published in response to this and other 
criticisms (e.g., Bryant, 2006; Confer et al., 2010; Geher, 2006; Hagen, 2005; Kurzban, 2002; Liddle, Bush, \& Shackelford, 2011; Liddle \& Shackelford, 2009; Sell, Hagen, Cosmides, \& Tooby, 2003), we will not provide an in-depth review here. We will, however, note that evolutionary psychologists acknowledge the important interactions that take place between one's genes and one's environment.

Furthermore, evolutionary psychologists do not argue that behaviors have evolved but rather that psychological mechanisms have evolved. Many of these mechanisms produce behavior, but only in response to specific environmental inputs. Without the appropriate input, a particular psychological mechanism will not produce any output. In fact, since violent behaviors are potentially very costly, evolutionary accounts suggest that we should only expect these behaviors under very specific conditions (i.e., in response to a specific and limited set of environmental inputs). The remainder of this chapter expands upon this premise, and we begin by examining violence in nonhuman animals.

\section{Red in Tooth and Claw: Violence in Nonhuman Animals}

The animal kingdom is not a peaceful kingdom. Aside from the obvious violence that occurs between species as predators attempt to make a meal out of their prey (see also Patterson-Kane \& Piper, Chapter 15, this volume, for another form of interspecies violence: animal abuse by humans), a substantial amount of violence occurs within species as well, and an evolutionary perspective can help explain why this occurs. A large portion of this violence, and the conditions in which it is expected to occur, can be explained by relying on two evolutionary theoretical models: sexual selection and parental investment theory.

\section{Sexual Selection}

The concept of sexual selection (Darwin, 1871) provides an important addendum to the theory of evolution by natural selection. Natural selection explains the evolution of complex traits as a result of heritable variations that influence differential survival. In any given population, some organisms are more likely to survive and subsequently pass on their genes than are others, and to the extent that heritable variations among organisms account for these differences in survival and reproduction, those variations will be selected for. Through this process, complex adaptations emerge as slight improvements in particular traits and continue to be selected for over thousands of generations. For example, computer simulations have indicated that a patch of light-sensitive cells can evolve into a complex eye through intermediate steps taking place over fewer than 400,000 generations, a brief period on an evolutionary timescale (Nilsson \& Pelger, 1994).

Although survivability is important, this is not the sole determinant of one's fitness (i.e., one's success in passing on his or her genes to the next generation), at least among sexually reproducing organisms. A sexually reproducing organism that lives for hundreds of years but never produces offspring will be no more successful, evolutionarily speaking, than an organism that dies immediately after birth. Therefore, selection will operate not only on traits that affect one's chances of survival but also on traits that affect one's reproductive potential. This fact can explain, for example, the evolution of the peacock's tail, a trait that initially tormented Darwin because it seemingly contradicted his theory of evolution by natural selection. The large, colorful tail is not only metabolically wasteful to produce but cumbersome as well, making it more difficult for peacocks to escape from predators. Natural selection would seemingly select against such a trait, since it is likely to have a negative impact on survival. However, Darwin (1871) came to realize that if peahens preferentially mate with peacocks that possess large tails, the cost to survival will be outweighed by the benefit to reproductive potential, and thus the trait will be sexually selected. In fact, the peacock's tail is likely preferred by peahens precisely because it is a harmful trait to possess, and any peacock that is capable of surviving with such a "handicap" is providing an honest signal that he possesses good genes (Zahavi \& Zahavi, 1996).

Sexual selection operates by two primary means: intrasexual competition and intersexual selection (Buss, 2011). The peacock's tail is an example of a trait produced by intersexual selection, in which a trait is selected for because it is preferred by the opposite sex. Intrasexual competition refers to competition between same-sex rivals for access to mating opportunities, and traits that improve one's chances of succeeding in such competition will be selected for. As we will see, both of these components of sexual selection, especially intrasexual competition, can help explain much of the violence that occurs within species. However, sexual selection alone provides us with an incomplete understanding of violent behavior. For example, in most species males are much more likely to engage in physically violent 
intrasexual competition than are females. To explain this robust sex difference, we must refer to parental investment theory.

\section{Parental Investment Theory}

Parental investment (Trivers, 1972) refers to the allocation of resources to offspring, at the expense of other potential sources of resource allocation (e.g., survival, mating effort, additional offspring). A key component of parental investment theory is that there is often a large discrepancy in the minimum obligatory parental investment provided to offspring by males and females, and this discrepancy can explain sex differences in regard to reproductive strategies, such as engaging in risky competition (e.g., physical violence) for mates.

In all mammals, females exhibit greater minimum obligatory parental investment than males. Females must devote considerable time and energy to their offspring due to internal fertilization and gestation, which is often followed by a period of nursing, whereas the minimum obligatory investment by males is the contribution of sperm. This results in females being far more discriminating when choosing a male to mate with, because there are much greater costs associated with not choosing wisely, such as potentially investing a great deal of resources into offspring with low prospects of survival due to bad genes. Therefore, females represent a limiting factor for male reproductive success, and as Ketelaar and Ellis (2000) describe, "Males should thus be selected to be more risk-taking and aggressive than females in pursuing sexual contacts, and to allocate more competitive effort toward monopolizing sexual access" (p. 7). Additionally, since greater maternal investment means that offspring rely on their mothers more than their fathers for survival, the costs of engaging in violent behavior are potentially much greater for females than for males. If a female is seriously injured or killed, any offspring that were being cared for by her, especially very young offspring, will be unlikely to survive (Sear \& Mace, 2008), and this would act as a strong selection pressure against predispositions to violence among females (see Campbell \& Cross, Chapter 12, this volume). The males of most species, since they provide little to no care to their offspring in the first place, have not been exposed to a similar selection pressure.

In summary, parental investment theory predicts that the sex that exhibits lesser obligatory parental investment (typically males) should be predisposed to violence because of the benefits of successfully competing with same-sex rivals (i.e., access to the "choosier" sex for mating), and the sex that exhibits greater obligatory investment (typically females) should be predisposed to avoid violence because of the costs associated with injury and death (i.e., being unable to care for one's offspring). The fact that the males of most animal species, particularly mammals, are overwhelmingly more prone to physical violence than are females (Ghiglieri, 1999) seemingly supports parental investment theory, but the predictive power of this theory is particularly evident when examining certain nonmammalian species in which the discrepancy in minimum parental investment is reversed between the sexes. For example, among certain species of birds, males invest more in their offspring than do females. Ghiglieri (1999) describes the behavioral results of this role reversal among Australian cassowaries:

... females are the aggressive (macho) sex.... these six-foot tall birds, armed with a three-inch claw/ spike that can disembowel a dingo, battle each other using brutal kicks. A victorious female then mates with as many males as she can find, one after the other. She leaves each with a clutch of her eggs. The males, who are one-third smaller than the females, dutifully incubate the eggs, driving off predators and sometimes going up to fifty days without food to protect the clutch.

(pp. 10-11)

Other "sex-role-reversed" species include the Mormon cricket, the pipefish seahorse, and the Panamanian poison arrow frog (Trivers, 1985, as cited in Buss, 2011). The males of these species invest more in their offspring than do females, and as parental investment theory predicts, they are more discriminating when choosing which females to mate with, while the females compete with each other, often violently, for access to males.

The theories of sexual selection and parental investment illustrate that violence among nonhuman animals is not arbitrary or pointless but instead is determined by calculations of costs and benefits. These calculations need not be made consciously, and as Campbell (2005) explains, "...emotionally driven information processing mechanisms have been honed through evolutionary time to trip a decision in a way that can seem automatic and unreflective" (p. 629). In other words, it seems plausible to posit that evolved psychological mechanisms for violence exist in nonhuman animals, and that these mechanisms generate violent behavior 
in response to specific inputs that indicate that the potential costs of violence are outweighed by the potential benefits. In the sections that follow, we describe what some of these inputs may be and how these inputs influence the cost-benefit calculations that determine the likelihood of engaging in violent behavior.

\section{To the Victor Belong the Spoils}

Some degree of violence has been observed in virtually every known animal population, and the majority of this violence exists in the context of resource competition, with one sought-after resource being access to mates (see Sherrow, Chapter 2, this volume). More specifically, it is typically males who engage in intrasexual violence as a way of competing for access to females. The females preferentially mate with the victors of these violent competitions, and the losers are largely, if not completely, excluded from mating opportunities.

The severity of violence can vary considerably, from male Japanese beetles engaging in "shoving matches" for access to mates, with the loser eventually being chased away (Hongo, 2003), to male red deer fighting intensely during the mating season, accounting for $13 \%-29 \%$ of adult male deaths (Clutton-Brock \& Albon, 1982). Given the high potential costs associated with violent intrasexual competition (e.g., severe injury or death), many species engage in intrasexual competition consisting of ritualized fighting (Maynard-Smith \& Price, 1973; Sherrow, Chapter 2, this volume), in which physical attacks are mostly replaced by violent displays. Those engaged in ritualized fighting can rely on several cues to "size up" their opponents (e.g., body size and physical condition; see Newton-Fisher \& Thompson, Chapter 3, this volume), thus limiting the need to commit to a fight to the death (or serious injury) if the likely victor can be identified.

This approach to intrasexual competition can be observed within chimpanzee communities. Male chimpanzees occasionally fight and injure each other, but intrasexual competition is more often conducted via displays that serve as cues to competitive ability, thus obviating any physical violence (Goodall, 1986). Ritualized fighting can also be observed among male sierra dome spiders, in which the likely loser can retreat before suffering any severe injuries. However, when a clear victor cannot be identified from ritualized fighting, neither competitor will back down because they both perceive that they may be victorious, and therefore the fighting will become more severe and often lead to severe injury or death (deCarvalho, Watson, \& Field, 2004).

One important factor that determines the degree of intrasexual competition in a species is the extent to which the losers of such competition are excluded from mating. The greater the exclusion, the higher the stakes, with the end result being more intense competition. One species that illustrates this concept well is the elephant seal. Mating is highly polygynous, with individual males forming and defending harems of females during breeding season. Males that are capable of defending a harem have exclusive access to the females of that territory, translating into huge reproductive success, whereas males who are incapable of defending a harem or taking over another male's harem are almost completely excluded from any mating opportunities. This reproductive context sets off an evolutionary arms race among males competing intrasexually for mating opportunities, resulting in extreme sexual dimorphism in which males are several times larger than females (Cartwright, 2000). Larger size has been selected for among males because it provides an advantage during violent intrasexual competition. Large size can be useful not only in the context of violent competition, but also it can serve as an honest signal of one's strength and prowess, thereby deterring potential competitions. Indeed, male elephant seals often rely on ritualized fighting displays to settle intrasexual competitions (Sanvito, Galimberti, \& Miller, 2007), but since the stakes are so high, violent competitions are not uncommon (Haley, 1994).

\section{This Land Is My Land}

The examples of intrasexual competition mentioned thus far illustrate the importance of a particular resource: access to mates. However, mating opportunities mean nothing if you or your offspring do not have access to food, a scarce commodity for many species. Therefore, access to food or feeding territories-when such resources are scarcerepresents a likely motivator of violent competition. For example, competition over food is not observed among mountain gorillas, who mostly eat leaves, stems, and piths, because they live in environments in which they are surrounded by potential food (Fossey, 1984), but this is not the case among blackand-white colobus monkeys, who defend valuable feeding territories from rival groups (Harris, 2006).

Unlike access to mates, which is a resource primarily fought for between males, food is an important resource for both males and females, perhaps 
even more important for females because they often need to provide for their offspring as well. Therefore, we should expect females to be willing to engage in violence to compete for food, although their willingness to engage in violence, relative to males, should still be mitigated by the higher potential costs, as explained by parental investment theory. Indeed, both male and female kangaroo rats engage in intrasexual and intersexual competition over seeds and suitable areas to cache seeds (Blaustein \& Risser, 1976). Additionally, female chimpanzees have been observed acting more aggressively than normal, almost approaching male levels of aggression, when food is scarce or feeding territories are at stake (Muller, 2007).

A particular form of competition for food and territory worth highlighting is coalitional violence, in which a group of individuals works together to attack a rival group or individual (see NewtonFisher \& Thompson, Chapter 3, this volume). Since this type of competition requires teamwork, it is primarily observed among social animals, particularly carnivores such as lions (Mosser \& Packer, 2009), African wild dogs (Creel \& Creel, 2002), hyenas (Boydston, Morelli, \& Holekamp, 2001), and wolves (Mech, 1977). Like intrasexual competition for mates, the likelihood of violence between groups is largely determined by the perceived difference in strength between competitors, but the cost-benefit calculations differ in this context. When competing for mates, males are less likely to engage in violence if a victor can be identified through violent displays. This makes sense because escalating the competition would not provide additional benefits to the victor, and the competitors are often males from the same group, which means they are potential allies if attacked by a rival group. But unlike competitors for mates within the group, rival groups that compete for food and territory represent a long-term threat, and the elimination of such threats whenever possible is desirable. Eliminating rival groups can produce long-term benefits, such as increased territory size, which translates into increased access to food and other resources. Therefore, the greater the perceived difference in strength between groups, the more likely the stronger group is to engage in violent competition. For example, among wolves, in which $25 \%-65 \%$ of adult deaths are due to coalitional violence, death is most likely when a lone wolf is confronted on the outskirts of their territory by a rival pack (Mech, Adams, Meier, Burch, \& Dale, 1998). A similar pattern is found among African lions, in which lethal violence is most likely when a pack comes into contact with a lone rival (Grinnell, Packer, \& Pusey, 1995).

The coalitional violence observed among male chimpanzees is especially noteworthy in that it most closely resembles human warlike behaviors. Male chimpanzees have been observed forming "raiding parties," in which a group of males stealthily investigates areas beyond their own group's territory, seemingly on the lookout for isolated (i.e., vulnerable) males from rival groups. Again, the difference in strength that so often mitigates violence during mate competition actually fuels violence in this context. This type of behavior was first observed by Goodall (1979) within 2 years of no longer giving chimpanzees at Gombe 600 bananas a day to habituate them to the presence of humans. Within this time period, the chimps at Gombe split into the Kasakela community (with roughly 35 members) in the north and the Kahama community (with roughly 15 members) in the south. There were seven males in the Kahama community, and at least five of them were systematically killed by male coalitions from the Kahama community, while the remaining two disappeared due to unknown causes. These murders were brutal and premeditated, and based on the severity of the wounds inflicted, it is clear that the goal was to kill rather than to injure the victims (Ghiglieri, 1999).

Although the events described earlier may have initially been viewed as anomalous behavior, a similar "war" was launched a decade later by chimpanzees in the Mahale Mountains, and as Ghiglieri (1999) describes, “...males of Nishida's huge M-Group (more than eighty chimps) systematically stalked and murdered the six adult males of the smaller, neighboring K-Group, which contained twenty-two chimps at the onset of hostilities" (p. 173). Among the chimpanzees of Kibale, three adult males of the Kanyawara community were killed by males of the Wantabu community between 1988 and 1994, an important finding because these chimps were never given food by observers, eliminating the possibility that previous observations of raiding were merely the result of altered lifestyles due to human involvement. Over the years, these observations have been supplemented by dozens of similar accounts observed among chimpanzees throughout Africa (see Newton-Fisher \& Thompson, Chapter 3, this volume).

Importantly, in the majority of cases of raiding and eliminating rival males, the victorious chimps benefitted from expanded territories (which provides additional food resources) and the assimilation of 
females from the defeated group (Ghiglieri, 1999). At the very least, victorious chimps benefit by no longer having to defend their resources from the eliminated rivals. It is also worth noting that when neighboring groups are roughly equal in size, raiding is rare, if it occurs at all (Ghiglieri, 1999). Given the large benefits and the low risks associated with violence when the target is outnumbered, it is not difficult to see why chimpanzees, under the proper conditions, are willing to engage in what can arguably be defined as warfare.

\section{Infanticide}

An additional form of violence among nonhuman animals that warrants our attention is infanticide, or the killing of same-species infants, which has been observed among many species of mammals (Hrdy, 1977, 1979; Janson \& van Schaik, 2000). Like other forms of violence, there appears to be an underlying evolutionary logic to infanticide, with both males and females engaging in this behavior but in different contexts. When males commit infanticide, it is almost exclusively unrelated infants who are killed, and the primary benefit of this act appears to be increased mating opportunities. More specifically, many female mammals who are nursing infants experience lactational amenorrhea and do not ovulate, but if the infant is killed, the female begins to cycle again (Hrdy, 1979). In other words, the female becomes available for mating following infanticide, and such females will often mate with the male who committed the infanticide. This type of infanticide is often observed in polygynous species, such as lions, when a new male comes into power and monopolizes mating opportunities after killing any unrelated infants (Newton-Fisher \& Thompson, Chapter 3, this volume; Pusey \& Packer, 1994).

When females commit infanticide, the target infant may either be related or unrelated, with a different evolutionary logic underlying the two types of infanticide. Females may kill unrelated infants when such behavior results in reduced present and future resource competition faced by her and her own offspring (see Sherrow, Chapter 2, this volume). An environment with scarce resources is not enough to evoke this type of infanticide; there must be intragroup competition for resources, and the elimination of unrelated infants must potentially result in increased access to these resources (Leland, Struhsaker, \& Butynski, 1984). This type of infanticide, along with the predicted prerequisite conditions, has been observed among ground squirrels (Waterman, 1984) and several species of birds (Mock, 1984).
Females also kill their own offspring, which may seem maladaptive from an evolutionary perspective, but it is important to keep in mind that the females of most species, particularly mammals, must invest substantially in their offspring. Given the high costs of parental investment faced by females, there are occasionally situations in which it is in the best interest of the female (in terms of her fitness) to forego paying those costs. For example, when resources are scarce and a female already has offspring, additional offspring may result in a lack of adequate distribution of resources among all of the offspring. In this case, it would be in the mother's interests to either directly or indirectly (via neglect) kill the new infant in order to increase the survival chances of her other offspring in whom she already has invested substantially (Hrdy, 2000; see also Harris, Hilton, \& Rice, Chapter 6, this volume). In short, infanticide among nonhuman animals can occur for many reasons, none of which are arbitrary, at least when considered from an evolutionary perspective.

\section{Summary}

The examples of violence among nonhuman animals described earlier illustrate that violence is not random or aberrant but functional. Violent behavior serves a purpose and is likely the result of evolved psychological mechanisms that, based on particular environmental inputs, calculate whether the costs of violence are outweighed by the potential benefits. These inputs include the availability of resources, including food, territory, and access to mates; the strength of one's opponent, which may be assessed via ritualized fighting displays; and the number of opponents, which is an important factor for determining the likelihood of coalitional violence against rival groups. Even when one's "opponent" does not represent a threat in terms of retaliation, as is the case with infants, the use of violence still relies on the calculation of costs and benefits to one's fitness, such as when a mother engages in infanticide to increase the survival prospects of her other offspring or her future offspring. But an important question remains: Is human violence similarly purposeful?

\section{The Most Dangerous Animal: Violence in Humans}

"Me against my brother," goes the old Arab proverb;

"me and my brother against my cousins; me, my

brother and my cousins against our nonrelatives; me, my brother, cousins and friends against our enemies 
in the village, all of these and the whole village against the next village."

—Ghiglieri, 1999, p. 170

The violent behaviors humans engage in may often seem senseless, particularly when one hears reports of school shootings, war atrocities, mass murders, and so forth. However, the preceding account of nonhuman animals suggests that violent behaviors are produced in order to solve particular adaptive problems, and therefore it is not unreasonable to conceive of an evolutionary functionality underlying many cases of violence among Homo sapiens. But the ubiquity and apparent functionality of violence throughout the animal kingdom is not the only line of evidence suggesting that violence serves a purpose in humans. Additional support for this idea comes from the evidence of violence committed by humans throughout our evolutionary history, which we examine next.

\section{A History of Violence}

Although there is much that we still do not know about the evolutionary history of humans (e.g., the emergence of language), the archaeological evidence for violence between early humans is indisputable. For example, human skeletons from the upper Paleolithic period have been found with projectile points imbedded in them and skeletal trauma that appears to have been caused by clubbing (Ferguson, 1997; Smith, Chapter 20, this volume). Smith (2007) describes several more examples of such violence:

A Neanderthal man who lived in a cave in Shanidar, Iraq, was stabbed in the side in what was probably a face-to-face confrontation; a young child was killed 30,000 years ago in what is now Grimaldi, Italy, when a spear pierced his tiny body and lodged deep in his spine; an Egyptian man met his death 20,000 years ago when two arrows entered his abdomen and a third lodged in his upper arm. (p. 45)

A cemetery at Jebel Sahaba in Northern Sudan dating back roughly 13,000 years provides particularly strong evidence of violence, and perhaps war, between early humans. Among the 59 bodies discovered there, almost half appear to have been killed by weapons, because arrowheads and barbs were discovered in and around their bones (see Smith, Chapter 20, this volume). Among the children buried there who met a violent end, the wounds indicate that they were executed, with arrows shot into their necks at close range (Smith, 2007). Similar examples of mass killings include mass burial sites in Germany, Bavaria, and France, all of which contain the skeletons of individuals who appear to have been killed violently, often by blows to the head (Keeley, 1996). Taken together, the archaeological findings discussed thus far represent the most direct evidence for violence between early humans.

Given the difficulty with finding skeletal remains from our early evolutionary history, it is likely that acts of violence were more common than what the archaeological evidence described earlier suggests. Fortunately, there are other pieces of evidence that highlight the violence that may have occurred between early humans. For example, the crafting of tools necessary for inflicting severe violence on other humans, such as stone axes and wooden spears, began at least 400,000 years ago (Smith, 2007), although such tools were clearly useful for other tasks as well, such as hunting. Additional evidence for the possibility of violence among early humans comes from Late Paleolithic paintings found in France, Spain, and Italy depicting humans being killed with arrows and spears (Smith, 2007). Moving ahead in our evolutionary history, the early writings of many civilizations provide additional details of human violence, particularly large-scale violence. Such writings come from a variety of societies, such as Egypt, Sumer, Greece, Rome, India, and Mesoamerica (Keeley, 1996). In particular, the Old Testament and Homer's Iliad provide extensive and graphic details of warfare (Carroll, Chapter 24, this volume; Gottschall, 2008), and although some of the violent stories depicted in these works are either clearly fictional or dubious, it seems likely that the authors were inspired by first- or secondhand accounts of similar violence.

Finally, the transition from nomadic lifestyles to permanent settlements beginning in the Neolithic period roughly 10,000 years ago provides further evidence that violence between humans represented an ongoing threat for our ancestors. This transition took place initially in the Fertile Crescent and was primarily driven by the advent of agriculture and the domestication of animals, which required humans to stay in one place to cultivate the land for food (Diamond, 1997). This new way of life led to larger populations, technological advancements, and, importantly, the stockpiling of resources, which made permanent settlements the focal points for violence between groups of humans. The fact that such violence occurred, or that it was at least a realistic threat, is evidenced by the architecture of 
early settlements. More specifically, those who built permanent settlements made sure to build protective walls, and as settlements grew in size and technology advanced, the fortifications became more elaborate and extensive (Smith, 2007). Given the labor and resources necessary to fortify settlements, it seems likely that attacks by other humans constituted a serious threat, a conclusion that is strengthened when the other evidence for violence described earlier is taken into account.

In summary, the evidence of violence throughout human evolutionary history serves as a powerful reminder that contemporary violence is not a new phenomenon. Although we cannot ascertain with any certainty the contexts in which most violence took place between our ancestors, our history suggests that we should not blame violent video games and other media as the sole or primary source of the violence we see in contemporary societies. Although certain novel aspects of contemporary environments may influence violent behavior (but see Ferguson \& Kilburn, 2009, for a meta-analysis indicating little to no effect of violent media on violent behavior), we believe that researchers should also focus on environmental factors that have been recurrent throughout our evolutionary history, as well as the recurrent adaptive problems that our ancestors faced, particularly those that could have been solved through violence. As we will see, mating represents one potential source for many of these types of adaptive problems.

\section{In the Name of Love}

As with many other animals, mating can serve as a direct or indirect catalyst for violence among humans, and the theories of sexual selection and parental investment can help explain why this occurs. Humans are unique among most species in terms of the typically large amount of paternal investment in offspring, but women still exhibit greater obligatory investment and thus represent a limiting factor for male reproductive success. Furthermore, men are roughly $120 \%-130 \%$ the weight of females (Ghiglieri, 1999), and this sexual dimorphism suggests a history of effective polygyny in which some men secure a greater number of mating opportunities at the expense of other men, thus increasing the variability of male reproductive success (Buss \& Shackelford, 1997).

As in other species, increased variability in reproductive success and lower obligatory parental investment relative to the opposite sex translate into fiercer and riskier intrasexual competition for mating opportunities (Campbell, 2005). Therefore, it is not surprising that men around the world are substantially more physically violent than are women. In the United States, roughly $87 \%$ of those who commit homicide, and $75 \%$ of those who fall victim to homicide, are men (Lester, 1991), a statistic that is similar, if not even more male biased, in other countries (Buss, 2005; Daly \& Wilson, 1988; Ghiglieri, 1999Additionally, the levels of mortality from violence are highest in young adulthood and decrease considerably as men marry, start families, and invest in their children, that is, when the search and competition for mating opportunities decreases (Kruger \& Fitzgerald, Chapter 10, this volume; Kruger \& Nesse, 2006). Although other factors may play a role in the high rates of violence among young men, the consistently higher mortality rate across the lifespan for men who have never married compared with men who have supports the idea that intrasexual competition is an important factor at any age in which a man is looking for a mate.

But how does violence translate into mating opportunities? It seems that both intrasexual competition and intersexual selection play important roles, in that intrasexual competition between men is often directly related to status or reputation, and women preferentially choose partners of high status, most likely because high status has historically translated into having access to more food, better territory, and greater social support, thus serving as an honest signal of a man's ability (but not necessarily intent) to provide for a woman and her offspring (Buss, 2005). Among the Yanomamö, Chagnon (1988) documented that roughly $40 \%$ of the men had participated in homicide, and these men had higher social status, as well as more wives, than those who had not participated in homicide. Nonlethal fights with clubs are also common among Yanomamö men, and they often take place in the context of competition over mates (Chagnon, 1992). Although the frequency of violence among the Yanomamö is higher than that found in many other tribal societies, the reasoning behind the violence is not unique. Indeed, many tribal societies bestow increased status and honor to men who have committed homicide (Daly \& Wilson, 1988). This phenomenon can even be found in the United States, particularly among gangs, in which the most violent gang members often have the highest status (Campbell, 1993) and the most sexual partners (Buss, 2011; Ghiglieri, 1999; Palmer \& Tilly, 1995). Even among children and adolescents who do not engage in criminal behavior, the 
importance of intrasexual competition over status can be observed in the context of bullying (see Volk, Camilleri, Dane, \& Marini, Chapter 16, this volume). Male bullies who pick on weaker individuals are able to acquire higher status (Vaillancourt, Hymel, \& McDougall, 2003), resources ranging from lunch money and books to leather jackets and designer sneakers (Buss, 2011; Olweus, 1978), and dating or mating opportunities (Connolly, Pepler, Craig, \& Taradash, 2000).

The importance that men place on status, and perceived threats to one's status, makes sense when we consider the small groups in which humans lived for the majority of our evolutionary history. We have inherited psychological mechanisms that evolved in response to a type of group living in which anonymity was mostly lacking, if not entirely absent. In other words, groups were small enough that everyone likely knew and repeatedly interacted with each other. In such an environment, failure to defend one's status or reputation when provoked by a rival would have been very costly, particularly for men, because of the message it would send to the rest of the community: "I am weak and exploitable." Such a message would have a severe impact on one's mating potential. With such high costs, violence could emerge as a viable strategy for defending one's status, or for ascending the status hierarchy, which would provide substantial benefits. Although the adaptive problem of status maintenance differs in large modern societies involving many interactions with people we may never see again, we still carry with us psychological mechanisms that are sensitive to perceived status threats. As Buss (2005) explains:

Though we may like to believe that societies today respect a man more for walking away from an insult or threat than for confronting it, such insults have powerful consequences, because of the deeply ingrained messages they send, messages our brains have evolved to read. An insult taken without retaliation sends a signal first to the one who hurled the words that he can get away with dominating the one he's offended.... it tells the challenger that he can tread on his victim's turf..., take over his territory, and he can come on to his wife or girlfriend if he chooses.... A challenge left unmet unfortunately also sends these messages to the crowd watching... Witnesses to the challenge may view the insulted person as exploitable, encouraging further infringements on his interests.

(p. 207)
In short, our evolutionary history has equipped men with a heightened sensitivity to perceived affronts to status and reputation. It is therefore not surprising to see that many male-on-male homicides result from seemingly "trivial altercations" that are best viewed as status contests (Buss, 2005; Daly \& Wilson, 1988). These altercations typically involve a man perceiving a slight to his status from another man who refuses to apologize, thus leading to an escalation of violence and, in some cases, homicide (Campbell, 2005).

Despite the overrepresentation of men in statistics regarding violent behavior, it is important to recognize that violence is not an exclusively male behavior. If it were, then we may expect, for example, that only men have homicidal fantasies. In reality, although a greater percentage of male college students in the United States admit to such fantasies $(80 \%)$, studies have shown that $60 \%$ of women admit to having homicidal fantasies as well (Buss, 2005; Kenrick \& Sheets, 1993). But the inclusion of women in the world of violence is not limited to fantasies. Although women represent the choosier sex due to their greater parental investment, they still engage in intrasexual competition for the highest quality mates (e.g., men with good genes, men likely to invest in offspring). This intrasexual competition is further necessitated by ecologically or socially imposed monogamy, which increases the choosiness of men looking for mates, particularly when they are looking for long-term mates (Campbell, 2005).

Since the potential costs associated with physical violence are often higher for women than for men, women often opt for other forms of violence when competing for mates. Female intrasexual competition for mates typically involves indirect or relational aggression, which consists of verbal derogation, gossip, spreading rumors, and other nonphysical forms of ostracism and stigmatization in which the victim is often "attacked" indirectly, thereby reducing the likelihood of retaliation (Björkqvist, Österman, \& Lagerspetz, 1994; Campbell \& Cross, Chapter 12, this volume). Although a meta-analysis by Archer (2004) suggests that there is little to no sex difference in the use of indirect aggression, the specific contexts in which this aggression is used do seem to differ. For example, women are more likely to gossip negatively about the physical appearance of intrasexual rivals than are men (Brown, 1998; Buss \& Dedden, 1990; Simmons, 2002). Given the priority that men place on physical attractiveness in potential mates (Buss, 2003), this proves to be a very 
effective strategy for derogating one's rivals. Women are also more likely to spread rumors about, or draw attention to, the sexual promiscuity of other women (Campbell, 1982; Campbell \& Cross, Chapter 12, this volume). This can be costly for the victim of such indirect aggression because sexual promiscuity serves as a cue to potential infidelity and is therefore an unattractive trait to men looking for a long-term partner. In summary, when women engage in intrasexual competition via indirect aggression, they specifically target traits in their rivals that will decrease their attractiveness to men looking for mates, particularly long-term mates.

Not all violence in the context of mating occurs intrasexually. Male violence directed at women, most often intimate partners, is a phenomenon that must be addressed. Every year, more than half a million women in the United States report being attacked violently by current or former intimate partners, and annual rates of violent victimization of women range from $14 \%$ to $16 \%$ (Buss \& Duntley, 2011). An evolutionary perspective can help explain why such violence occurs (see Camilleri, Chapter 11, this volume; Goetz \& Romero, Chapter 4, this volume). As mentioned earlier, humans are unique in the animal kingdom in terms of the substantial investment that men often make in their offspring. However, until the very recent possibility of DNA testing, men could never be certain that their putative offspring were genetically their own. Therefore, the possibility of cuckoldry (i.e., having an unfaithful partner and subsequently investing in genetically unrelated offspring) has represented a serious adaptive problem for men throughout our evolutionary history.

The costs of cuckoldry are severe; not only would a cuckold be increasing the fitness of a rival by investing in his offspring, but the cuckold's own fitness would also suffer as he continues to spend resources that could be allocated to his genetically related offspring (if he has any) or to future offspring. Given contemporary estimates of worldwide cuckoldry that range from $1 \%$ to $30 \%$ (Goetz, Shackelford, Platek, Starratt, \& McKibbin, 2008), it is likely that cuckoldry occurred often enough throughout our evolutionary history to have imposed strong selection pressures on men. Therefore, we should expect male psychology to have been shaped by this adaptive problem, resulting in psychological mechanisms for detecting and preventing cuckoldry. And as we have seen throughout this chapter, when an adaptive problem carries such extraordinary costs, violence may emerge as a viable solution.
To prevent cuckoldry, men are extremely sensitive to the possibility of female sexual infidelity, and cues to infidelity serve as powerful inputs to the psychological mechanisms that evolved in response to this adaptive problem. In fact, men exhibit an overperception of partner infidelity, in that they are generally more likely than women to judge their partners as being unfaithful in the future (Goetz \& Causey, 2009). Since false positives (perceiving infidelity when it has not occurred) are less costly to men's fitness than false negatives (not perceiving infidelity when it has occurred), men have evolved mechanisms that generate overperceptions of the possibility of partner infidelity.

Simply perceiving cues to infidelity is not enough to prevent cuckoldry. Such cues initiate sexual jealousy, which in turn motivates behaviors that function to eliminate the threat of cuckoldry. Unfortunately, the behaviors that are motivated can often be violent. Indeed, one of the most frequently cited causes of intimate partner violence, as well as homicide, is male sexual jealousy (Goetz, Shackelford, Romero, Kaighobadi, \& Miner, 2008), and men's partner-directed violence is often predicted by men's perceived risk of partner infidelity (Kaighobadi \& Shackelford, 2009). Violence can effectively restrict an intimate partner's behavior, thus limiting the possibility of infidelity (Goetz, Shackelford, Romero, et al., 2008). If it is suspected that sexual infidelity occurred recently, men may engage in sexual coercion, thereby minimizing the risk of cuckoldry via sperm competition. This hypothesis is supported by research indicating that men are more likely to engage in sexual coercion when the perceived risk of cuckoldry is high (Goetz \& Shackelford, 2006; Lalumière, Harris, Quinsey, \& Rice, 2005; Thornhill \& Palmer, 2000; Wilson \& Daly, 1992). Although these behaviors are clearly abhorrent, they do not appear to be arbitrary or merely a manifestation of men's desire for power and dominance. Rather, they ultimately stem from selection pressures acting on men throughout evolutionary history to minimize the possibility of female sexual infidelity and subsequent cuckoldry.

\section{All in the Family}

Of course, not all violence among humans is restricted to the context of mating. As in other species, additional resources besides access to mates (e.g., food, one's time and energy) serve as sources of conflict, and one arena in which such conflicts may occur is within the family. But when discussing violence within families, it is important to consider the 
genetic relatedness of family members. According to kin selection theory (Hamilton, 1964), organisms should be more altruistic and less competitive toward others as a function of their genetic relatedness. Helping a genetic relative and increasing that person's fitness, even at a cost to oneself, can ultimately be beneficial to the altruist because of the genes he or she shares with the beneficiary. In other words, increasing a genetic relative's fitness will result in some of one's own genes being passed on to future generations, thereby increasing one's inclusive fitness. With this important caveat in mind, it is no surprise that a substantial proportion of violence, particularly homicides, within families takes place between individuals who are not genetically related (Campbell, 2005). For example, among 508 Detroit homicides in 1972, 25\% occurred between relatives, but only $6.3 \%$ involved genetic relatives, a pattern found consistently across societies and time periods (Daly \& Wilson, 1988). However, even though these findings are consistent with kin selection theory, they also illustrate that genetic relatedness does not always prevent violence.

Despite the lower levels of competition between genetic relatives predicted by kin selection theory, competition and violence do occur. Since genetic relatives (identical twins notwithstanding) only share a portion of their genes with each other, conflicts of interest are expected, with violence sometimes occurring as a result. One example of such conflict is that between siblings. Sibling violence is the most common type of nonlethal violence within families (Wiehe, 1997). Siblings compete with each other for limited parental resources. Throughout human evolutionary history, and in many other species, the primary resource competed over would be food, but in contemporary societies siblings most often compete for time, attention, and money (see Salmon, Chapter 7, this volume). This competition can often turn violent, with $74 \%$ of children pushing and shoving their siblings and $42 \%$ kicking, biting, or punching their siblings, according to a recent national study of family violence (Straus, Gelles, \& Steinmetz, 2006). Violence between siblings is more likely to occur the closer they are to each other in terms of age, and also if they are the same sex (Sulloway, 1996). This may be due to the fact that siblings of the same sex and similar age desire similar resources. Violence between siblings, especially older male siblings, can sometimes escalate to homicide, although the murder of a sibling (i.e., siblicide) is rare, accounting for roughly $1 \%$ of homicides in the United States (Underwood \& Patch, 1999).
Another form of within-family violence occurs between parents and offspring. As explained earlier, women must invest heavily in their offspring, and this investment is obligatory. The high costs of maternal investment can also help explain a particularly abhorrent example of within-family violence: filicide (see Harris, Hilton, \& Rice, Chapter 6 , this volume). The murder of one's children, particularly newborns (i.e., infanticide), is one of the few cases of extreme violence that is perpetrated by women more often than men (Bourget, Grace, $\&$ Whitehurst, 2007). Given the high costs associated with investing in offspring, female psychology is likely to have been shaped in such a way as to forego paying these costs when the desired outcome of investment (i.e., a reproductively capable adult) is unlikely to occur. Examples of such a situation include low infant quality (e.g., deformities or illness) or a lack of adequate resources for investment (e.g., poverty, absence of male support, investment in older offspring), and Daly and Wilson (1988) have found that these contexts predict maternal infanticide across cultures.

As children get older, the possibility of filicide being perpetrated by the mother decreases substantially, which makes sense given how much the mother has already invested in the child. Indeed, women who kill their older children are often diagnosed with mental illness (Harris, Rice, Hilton, Lalumière, \& Quinsey, 2007). However, children are still at risk from other members of the family, particularly stepparents. Although most stepparents do not perpetrate violence against their stepchildren, the presence of a stepparent in the home is the single largest predictor of child abuse and filicide, with preschool-aged stepchildren suffering from a risk of filicide that is 40 to 100 times higher than children living with their genetic parents (Daly \& Wilson, 1988). The lack of genetic relatedness most likely plays an important role, and this finding powerfully illustrates the importance of applying an evolutionary perspective to violence, since the presence of stepparents was not identified as a risk factor until child abuse was studied by evolutionary psychologists (Buss, 2011).

Finally, perhaps the most difficult violence to explain from an evolutionary perspective occurs when there are seemingly no conflicts of interest: taking one's own life. Admittedly, some cases of suicide, particularly those committed after perpetrating familial homicide, can best be explained as a result of mental illness (see Liem, Chapter 8 , this volume). However, even though there initially 
appears to be no evolutionary logic underlying suicide, this assumption falls apart upon closer inspection (see Brown \& Brown, Chapter 9, this volume). For example, attempted suicide is often described as "a cry for help," and it is feasible that such behavior may have been selected for as a strategy for leveraging resources and help from social partners (Watson $\&$ Andrews, 2002) or investment from parents in the case of adolescents (Andrews, 2006). The costliness of such a strategy may be advantageous in that it serves as an honest signal of one's need for help. Evidence consistent with this hypothesis includes the observations that those who deliberately harm themselves often have needs that have been unmet, have difficulty communicating their needs to others, and ultimately benefit from self-harm by receiving more attention and help from others (Hagen, Watson, \& Hammerstein, 2008).

As for those who go beyond self-harm and commit suicide, there is clearly no direct benefit to the individual, but this behavior could have been selected for based on benefits to one's inclusive fitness. If one's reproductive potential is very low, then the possibility of passing on one's genes depends on the reproductive success of one's genetic relatives. However, if one also happens to be a burden to genetic relatives, his or her potential for reproductive success may be diminished. Therefore, the combination of low reproductive potential and burdensomeness to genetic relatives represents a scenario in which suicide may increase the potential for a portion of one's genes to be passed on to future generations (deCatanzaro, 1986). In short, suicide may improve inclusive fitness in specific situations, thereby leading to the selection of genes involved in the act of suicide, which has a heritability of roughly $40 \%$ (McGuffin, Marusic, \& Farmer, 2001). Consistent with this hypothesis, many studies of suicide and the risk of suicide have discovered an association with factors related to low reproductive potential (e.g., old age, low family income, low fertility) and burdensomeness to genetic relatives (e.g., as self-reported, as rated by clinicians, as documented in suicide notes) (Calzeroni, Conte, Pennati, \& Vita, 1990; Goodman, 1999; Joiner et al., 2002, 2003; Motto \& Bostrom, 1990; World Health Organization, 2010).

\section{That Atrocity of Atrocities, War}

Man is the only animal that deals in that atrocity of atrocities, War. He is the only one that gathers his brethren about him and goes forth in cold blood and calm pulse to exterminate his kind. He is the only animal that for sordid wages will march out... and help to slaughter strangers of his own species who have done him no harm and with whom he has no quarrel.... And in the intervals between campaigns he washes the blood off his hands and works for "the universal brotherhood of man" — with his mouth.

_Mark Twain, 1896/1992, p. 210

Any comprehensive discussion of human violence would be incomplete without an analysis of war. Although it is difficult to determine when humans began engaging in warfare, the raiding behavior of chimpanzees suggests that warlike behaviors have been a part of the human behavioral repertoire for the majority of, if not the entirety of, our evolutionary history. However, as the Twain quote illustrates, humans engage in warfare on a scale that is unmatched throughout the rest of the animal kingdom. This increase in scale was likely set into motion when humans shifted from nomadic lifestyles to living in permanent settlements. As settlements and their stockpiled resources grew, the benefits of conquering neighboring settlements increased, as did the potential costs associated with increasing defenses. Indeed, archaeological evidence of Native American settlements indicates that increased defense was related to geographic regions and time periods marked by resource scarcity and climatic unpredictability, factors that would have served as an impetus for warfare in order to plunder precious resources from rival settlements (Lambert, Chapter 19, this volume; LeBlanc, 1999).

Engaging in war, whether it occurs between tribes or countries, is almost exclusively a male enterprise (see Browne, Chapter 22, this volume; Van Vugt, Chapter 17, this volume). There are several factors that can help explain this, such as the differential costs of violence for men and women due to differences in parental investment, increased mating opportunities that result from controlling resources and territory (van der Dennen, 1995), and access to mates from the defeated rival's community (Campbell, 2005). The link between warfare and mating is further supported by the recent finding that men, but not women, are more likely to endorse war-supporting statements when exposed to photographs of attractive members of the opposite sex (Chang, Lu, Li, \& Li, 2011). In short, the potential benefits of warfare have been greater for men than for women throughout our evolutionary history, whereas the potential costs have been greater for women than for men. This created a selection pressure for men to be capable of forming alliances 
with other men in order to engage in coalitional aggression, with the goal of acquiring or defending resources relevant to survival and reproduction.

The ability to form cohesive male coalitions and successfully attack rivals is also dependent on a clearly perceived distinction between the ingroup and outgroup, along with ingroup amity and outgroup enmity (Durrant, 2011). Humans likely inherited this capacity from a much earlier ancestor, because as Smith (2007) explains, "Contact with a stranger of the same species is the most potent trigger for aggressive behavior among nonhuman animals, and it has been observed in virtually every species with complex social lives" (p. 74). However, studies indicate that men are more likely to display racism and xenophobia than women, particularly in threatening situations (Gerard \& Hoyt, 1974; Schaller, Park, \& Mueller, 2003).Thus, male perceptions of outgroups seem to be particularly tuned to facilitate intergroup aggression.

Despite the potential benefits of engaging in war and male psychological predispositions that facilitate going to war, the potential injury and loss of life still represent substantial costs that are likely to select against such behavior unless certain conditions are met to offset these costs. Tooby and Cosmides (1988) have argued that there are at least four such conditions: (1) average long-term gains in reproductive resources outweigh the reproductive costs of war; (2) the belief that one's group will be victorious; (3) receiving benefits commensurate with one's contribution and degree of risk taken; and (4) an inability to accurately predict which group members will live or die. In short, conditions that increase the perceived benefits and decrease the perceived costs will facilitate the willingness of men to engage in warfare.

\section{Individual and Cultural Differences in Violence}

The evolutionary accounts of human violence discussed thus far have not adequately addressed the issue of individual differences. For example, even though men are more predisposed to behave violently than women in particular contexts, it is not the case that every man will react with violence when insulted in public or when catching his partner with another man. Evolutionary psychology is often focused on identifying adaptations that are either "universal" among humans or sex specific, and for a long time individual differences were ignored or viewed as unimportant. In recent years, however, evolutionary psychologists have begun to acknowledge the importance of individual differences. Progress is being made in regard to explaining individual differences from an evolutionary perspective (see Buss, 2009), and this progress also applies to individual differences in violent behavior.

Life history theory provides a powerful framework for understanding individual differences from an evolutionary perspective, and it is based on the premise that organisms face trade-offs when deciding how to allocate their time, energy, and other resources to various aspects of survival and reproduction, because these resources are finite (Kruger \& Fitzgerald, Chapter 10, this volume; Stearns, 1992). There is no single strategy of allocation that is optimal, and thus individual differences are to be expected as a result of different ecological conditions and ontogenetic experiences. The trade-offs most relevant to understanding individual differences in violence are those between current and future reproduction, and between quantity of offspring and investment in offspring. When organisms opt to produce a large quantity of offspring with little investment in each, they are also prone to engage in riskier behavior, including violence, in order to successfully compete with intrasexual rivals and secure mating opportunities. Not surprisingly, the males of most species are more likely to engage in this "r-selected," or fast, life history strategy, than females, who generally provide greater obligatory investment in offspring and thus engage in a "K-selected," or slow, life history strategy by default (Stearns, 1992).

These strategies are not fixed across an organism's life span. For example, men are most likely to engage in a fast strategy during young adulthood, defined by the peak of risky and violent behavior in this age group (Kruger \& Nesse, 2006). Across species, the preferred strategy varies as a function of unpredictability in the environment, with uncertain conditions fostering a fast strategy. The logic behind this is that one's prospects for reproductive success in the future are uncertain, so the best strategy is to allocate resources to mating effort now. This logic can also explain individual differences in human violence, particularly among men. In the United States, the sex difference in mortality rates is higher for those in lower income groups and those with low educational attainment, both factors that influence one's certainty of future success (Kruger \& Nesse, 2006). Across societies, male mortality is disproportionally higher when economic inequality is greater (Kruger, 2010). The effect of an uncertain future on violence can also be seen when examining the 
economic transitions that took place in Central and Eastern Europe in the 1990s. The transition from the socialist period to market economies resulted in greater variance in social status and resource acquisition, and it also resulted in increased sex differences in mortality rates (Kruger \& Nesse, 2007). When the future is uncertain, men seem to engage in more risky and violent behavior, which suggests that they are engaging in greater intrasexual competition in order to increase their current reproductive success.

As some of the earlier examples illustrate, environmental conditions can produce differences in violence at the societal level. Another environmental factor that can help explain differences in violence, particularly intergroup violence, between societies is parasite prevalence (see Letendre, Fincher, \& Thornhill, Chapter 21, this volume). Throughout our evolutionary history, parasites have constituted a serious adaptive problem, resulting in an evolutionary arms race between the ability of humans to resist infection from local parasites and the ability of local parasites to bypass this resistance. The adaptive problem of parasites has additionally resulted in selection pressures on human psychology to produce behaviors that help one avoid infection. Fincher, Thornhill, and colleagues have developed the parasite stress model, which posits evolved psychological mechanisms that assess parasite prevalence in the surrounding region and, based on this assessment, motivate behaviors that manage the risk of exposure. More specifically, in regions of high parasite stress, humans are likely to embrace values that minimize interaction with outgroup members, such as collectivism, ethnocentrism, and xenophobia (Fincher, Thornhill, Murray, \& Schaller, 2008).

Unfortunately, this adaptive response reduces the possibility of cooperation between groups in regions of high parasite stress and increases the likelihood of autocracies (Thornhill, Fincher, \& Aran, 2009; Thornhill, Fincher, Murray, \& Schaller, 2010). As a result, such collectivist societies often suffer from poverty and inequality, which leads to withinstate fractionation and violence in competition for resources. An analysis of two data sets on intrastate armed conflict around the world confirmed that pathogen stress positively predicts the frequency of such violence, from small-scale conflicts to largescale civil wars (Letendre, Fincher, \& Thornhill, 2010; Letendre et al., Chapter 21, this volume).

Cultural values can play an important role in societal differences in violence, and another example of this effect can be found among "cultures of honor" (see Brown \& Osterman, Chapter 13, this volume).
In cultures of honor, which have been documented throughout the world (Daly \& Wilson, 1988), the male predisposition to defend one's status and reputation with violence is strengthened. Men from cultures of honor are not more violent in general, but they are more likely to resort to violence when they perceive an intrasexual threat to their status (Cohen \& Nisbett, 1994).

A prime example of the culture of honor consists of White men from the southern United States, who exhibit a higher homicide rate than White Northerners in relation to "trivial altercations" concerning one's reputation (Nisbett, 1993). White Southern males are primarily descended from Ulster Scots, who settled in the region during the 18th and 19th centuries. Cultures of honor are most likely to manifest in response to long periods of resource deprivation, a strong likelihood of a man's resources being thieved by other men, and the lack of a strong governing body or law enforcement to prevent thievery (Shackelford, 2005). Ulster Scots suffered these conditions between roughly 1000 and 1750 A.D. (Fischer, 1989). They also faced similar conditions in the southern United States because they primarily engaged in herding, which involved a greater potential for theft compared to the northern emphasis on farming. Furthermore, the South was marked by weak law enforcement and state power well into the 19th century (Shackelford, 2005). Although these facts can explain why the culture of honor originated in the South, additional research is needed to better understand why these cultural values persist in the present day.

Another aspect of culture that deserves consideration when discussing societal differences in violence is religion. Although a discussion of whether religion is ultimately a positive or negative influence on humanity is beyond the scope of this chapter, we would be remiss if we did not reference the extreme acts of violence that have been committed in the name of one religion or another throughout human history, such as the Crusades and other military conquests, the Inquisitions, subjugation and oppression of women (see Hartung, Chapter 5, this volume), and acts of terrorism that are often motivated, at least in part, by religious beliefs (Liddle et al., 2010; Sosis, Phillips, \& Alcorta, Chapter 14, this volume). In addition to these examples, it is important to note that one's religion often serves as a powerful source of ingroup identity, thus marking all of those who do not share one's beliefs as the outgroup. Although this can result in increased prosociality among ingroup members, it is unlikely 
to increase prosociality toward outgroup members unless one can improve his or her reputation by engaging in such behavior (Norenzayan \& Shariff, 2008). Despite certain religious scriptures that may profess the unity of all humankind, our psychological predispositions to ingroup amity and outgroup enmity are difficult to override (see Cikara, Bruneau, \& Saxe, 2011). This heightened perception of the ingroup and outgroup may partially explain why largely irreligious societies are less likely to go to war, especially unprovoked war (see Paul, Chapter 25 , this volume), although additional research must be done to determine whether there is any causal relationship.

\section{Conclusion}

Violence exists in a variety of forms and is elicited by a variety of contexts and inputs. Violent behaviors in humans and other animals are not arbitrary; rather, they appear to have been selected for to solve particular adaptive problems. In a broad sense, violence can be viewed as a strategy employed in the competition for resources. The scope and severity of violent behaviors are largely dependent on what resource is being competed for, who the competitors are, and the costs and benefits of engaging in violence in the particular context. Although this is an oversimplification, it illustrates that there is an evolutionary logic to be found behind most acts of violence, and acknowledging this is an important step toward better understanding why violence occurs.

Despite the accounts of violence described throughout this chapter, it should be noted that humans and many other species also have a tremendous capacity for cooperation. Far more time is spent engaging in cooperation, or at least peaceful coexistence, than is spent engaging in violence. But when violence does occur, it can often overshadow our altruistic side. This should not be misinterpreted as suggesting that we are "naturally good" and that violence represents a deviation from human nature. We are not naturally good or naturally evil; we are both. Our ancestors, the unbroken line of individuals who successfully passed on their genes to future generations eventually leading to us, are those who successfully used violence and cooperation to solve specific adaptive problems. Violence and cooperation, in their myriad forms, represent the output of evolved psychological mechanisms.

It is important to keep in mind that just because violence may be "natural," that does not serve as a justification for such behavior. We must avoid committing the naturalistic fallacy and concluding that people today ought to be violent because it served an adaptive purpose for our ancestors, or even if it continues to serve an adaptive purpose today. We also need to remember that an evolutionary explanation for violence does not imply that such behavior is inevitable or impossible to prevent. By studying violence from an evolutionary perspective, analyzing the contexts in which it occurs and the stimuli that influence its occurrence, we can gain a better understanding of the mechanisms that produce violence, thus putting us in a better position to limit the activation of such mechanisms.

\section{Future Directions}

Studying violence from an evolutionary perspective requires focusing on a multitude of contexts in an attempt to pinpoint the specific inputs that are likely to activate the psychological mechanisms that generate violent behaviors. Given the variety of violent behaviors in which humans and other animals engage, along with the various stimuli that elicit these behaviors, the possibilities for future research are vast. In regard to the examples of violence that were addressed throughout this chapter, the evolutionary explanations offered here are by no means the final say on why these specific acts of violence occur. Additional research is needed to understand the specific inputs that activate violence-producing mechanisms and to unravel the complex interactions between environmental stimuli (including one's experiences throughout development) and one's genotype. Furthermore, it is important to gain a better understanding of how violence affects those who witness it, particularly the developmental effects of exposure to violence (see Belsky, Chapter 23, this volume).

Although male violence against intimate partners has garnered more attention by evolutionary psychologists and the social sciences in general, female violence against intimate partners must also be addressed (see Campbell \& Cross, Chapter 12, this volume). In fact, women initiate both verbal and physical attacks on their partners at higher rates than do men (DeMaris, 1992; de Weerth \& Kalma, 1993). The evolutionary logic behind this behavior must diverge to some degree from male-perpetrated intimate partner violence, which is driven in large part by paternity uncertainty and the threat of cuckoldry. Therefore, researchers must focus on identifying the contexts in which female-perpetrated intimate partner violence takes place and determining whether such behavior serves (or may have 
served at some point in our evolutionary history) an adaptive purpose.

The issue of whether violence constitutes an adaptation is particularly contentious with regard to homicide. Although some evolutionary psychologists have attempted to explain homicide as a "slip up" of psychological mechanisms designed to produce nonlethal violence (Daly \& Wilson, 1988; Kenrick \& Sheets, 1993), others argue that some homicides are the result of mechanisms designed specifically for producing lethal violence (Duntley $\&$ Buss, 2011). Although both camps agree that neither explanation can apply to all cases of homicide, additional research must be conducted to determine which homicides perpetrated by humans support the by-product theory and which support the adaptation theory. One potential method may be to investigate any genetic differences between individuals who have committed a particular form of violent behavior and those who have not. Although it is difficult to uncover the genetic foundations of complex behaviors, researchers have had some success in linking genes to violence, aggression, and other antisocial behaviors (see Ferguson \& Beaver, 2009).

Finally, as important as it is to apply an evolutionary perspective to violence, we must also work toward an evolutionary psychological understanding of peace (see Dess, Chapter 26, this volume). As we noted earlier, despite the human capacity for violence, we also have a capacity for cooperation and peace, and we should attempt to gain a better understanding of the psychological mechanisms that generate such behavior, particularly by identifying the contexts in which peaceful coexistence is most likely to occur. For example, the weakening of male dominance hierarchies appears to play an important role in diminishing intergroup conflicts, presumably by weakening the control and coercion of females and promoting the development of democracy (see Hudson \& Den Boer, Chapter 18, this volume). By further investigating this phenomenon and other factors that appear to be related to the emergence of peace, we may learn what global changes are needed to increase the likelihood of peaceful interactions throughout the world.

\section{References}

Andrews, P. W. (2006). Parent-offspring conflict and cost-benefit analysis in adolescent suicidal behavior: Effects of birth order and dissatisfaction with mother on attempt incidence and severity. Human Nature, 17, 190-211.

Archer, J. (2004). Sex differences in aggression in real world settings: A meta-analytic review. Review of General Psychology, 8, 291-322.
Björkqvist, K., Österman, K., \& Lagerspetz, K. M. J. (1994). Sex differences in covert aggression among adults. Aggressive Behavior, 20, 27-33.

Blaustein, A. R., \& Risser, A. C. (1976). Interspecific interactions between three sympatric species of kangaroo rats (Dipodomys). Animal Behaviour, 24, 381-385.

Bourget, D., Grace, J., \& Whitehurst, L. (2007). A review of maternal and paternal filicide. Journal of the American Academy of Psychiatry and Law, 35, 74-82.

Bowles, S. (2006). Group competition, reproductive leveling, and the evolution of human altruism. Science, 314, 1569-1572.

Boydston, E. E., Morelli, T. L., \& Holekamp, K. E. (2001). Sex differences in territorial behavior exhibited by the spotted hyena (Hyeanidae, Crocuta crocuta). Ethology, 107, 369-385.

Brown, L. M. (1998). Raising their voices: The politics of girls' anger. London: Harvard University Press.

Bryant, G. A. (2006). On hasty generalization about evolutionary psychology: A review of David Buller, Adapting minds: Evolutionary psychology and the persistent quest for human nature. American Journal of Psychology, 119, 481-487.

Buss, D. M. (2003). The evolution of desire: Strategies of human mating (Rev. ed.). New York: Basic Books.

Buss, D. M. (2005). The murderer next door: Why the mind is designed to kill. New York: Penguin.

Buss, D. M. (2009). How can evolutionary psychology successfully explain personality and individual differences? Perspective on Psychological Science, 4, 359-366.

Buss, D. M. (2011). Evolutionary psychology: The new science of the mind (4th ed.). Boston: Pearson.

Buss, D. M., \& Dedden, L. A. (1990). Derogation of competitors. Journal of Personal and Social Relationships, 7, 395-422.

Buss, D. M., \& Duntley, J. D. (2011). The evolution of intimate partner violence. Aggression and Violent Behavior, 16, 411-419.

Buss, D. M., \& Shackelford, T. K. (1997). Human aggression in evolutionary psychological perspective. Clinical Psychology Review, 17, 605-619.

Calzeroni, A., Conte, G., Pennati, A., \& Vita, A. (1990). Celibacy and fertility rates in patients with major affective disorders: The relevance of delusional symptoms and suicidal behavior. Acta Psychiatrica Scandinavia, 82, 309-310.

Campbell, A. (1982). Female aggression. In P. Marsh \& A. Campbell (Eds.), Aggression and violence (pp. 137-150). Oxford, England: Blackwell.

Campbell, A. (1993). Men, women, and aggression. New York: Basic Books.

Campbell, A. (2005). Aggression. In D. M. Buss (Ed.), The handbook of evolutionary psychology (pp. 628-652). Hoboken, NJ: Wiley.

Cartwright, J. (2000). Evolution and human behavior: Darwinian perspectives on human nature. Cambridge, MA: MIT Press.

Chagnon, N. A. (1988). Life histories, blood revenge, and warfare in a tribal population. Science, 239, 985-992.

Chagnon, N. A. (1992). Yanomamö (4th ed.). Fort Worth, TX: Harcourt Brace Jovanovich.

Chang, L., Lu, H. J., Li, H., \& Li, T. (2011). The face that launched a thousand ships: The mating-warring association in men. Personality and Social Psychology Bulletin, 37, 976-984.

Cikara, M., Bruneau, E. G., \& Saxe, R. R. (2011). Us and them: Intergroup failures of empathy. Current Directions in Psychological Science, 20, 149-153. 
Clutton-Brock, T. H., \& Albon, S. D. (1982). Winter mortality in red deer (Cervus elaphus). Journal of Zoology, 198, $515-519$.

Cohen, D., \& Nisbett, R. E. (1994). Self-protection and the culture of honor: Explaining Southern homicide. Personality and Social Psychology Bulletin, 20, 551-567.

Confer, J. C., Easton, J. E., Fleischman, D. S., Goetz, C., Lewis, D. M., Perilloux, C., \& Buss, D. M. (2010). Evolutionary psychology: Controversies, questions, prospects, and limitations. American Psychologist, 65, 110-126.

Connolly, J., Pepler, D., Craig, W., \& Taradash, A. (2000). Dating experiences of bullies in early adolescence. Child Maltreatment, 5, 299-310.

Cornwell, R. E., Palmer, C., Guinther, P. M., \& Davis, H. P. (2005). Introductory psychology texts as a view of sociobiology/evolutionary psychology's role in psychology. Evolutionary Psychology, 3, 355-374.

Coyne, J. (2009). Why evolution is true. New York: Viking Penguin.

Creel, S., \& Creel, N. M. (2002). The African wild dog: Behavior, ecology, and conservation. Princeton, NJ: Princeton University Press.

Dahlberg, L. L., \& Krug, E. G. (2002). Violence-a global public health problem. In E. G. Krug, L. L. Dahlberg, J. A. Mercy, A. B. Zwi, \& R. Lozano (Eds.), World report on violence and health (pp. 1-22). Geneva, Switzerland: World Health Organization.

Daly, M., \& Wilson, M. (1988). Homicide. New York: Aldine de Gruyter.

Darwin, C. (1859). On the origin of species by means of natural selection. London: John Murray.

Darwin, C. (1871). The descent of man, and selection in relation to sex. London: John Murray.

deCarvalho, T. N., Watson, P. J., \& Field, S. A. (2004). Costs increase as ritualized fighting progresses within and between phases in the sierra dome spider, Neriene litigiosa. Animal Behaviour, 68, 473-482.

deCatanzaro, D. (1986). A mathematical model of evolutionary pressures regulating self-preservation and self-destruction. Suicide and Life-Threatening Behavior, 16, 166-181.

DeMaris, A. (1992). Male versus female initiation of aggression. In E. C. Viano (Ed.), Intimate violence: International perspectives (pp. 111-120). Washington, DC: Hemisphere.

de Weerth, C., \& Kalma, A. P. (1993). Female aggression as a response to sexual jealousy: A sex role reversal? Aggressive Behavior, 19, 265-279.

Diamond, J. (1997). Guns, germs, and steel: The fates of human societies. New York: W.W. Norton.

Duntley, J. D., \& Buss, D. M. (2011). Homicide adaptations. Aggression and Violent Behavior, 16, 399-410.

Durrant, R. (2011). Collective violence: An evolutionary perspective. Aggression and Violent Behavior, 16, 428-236.

Ellis, B. J., \& Bjorklund, D. F. (Eds.) (2005). Origins of the social mind: Evolutionary psychology and child development. New York: Guilford Press.

Ferguson, C. J., \& Beaver, K. M. (2009). Natural born killers: The genetic origins of extreme violence. Aggression and Violent Behavior, 14, 286-294.

Ferguson, C. J., \& Kilburn, J. (2009). The public health risks of media violence: A meta-analytic review. The Journal of Pediatrics, 154, 759-763.

Ferguson, R. B. (1997). Violence and war in prehistory. In D. L. Martin \& D. W. Frayer (Eds.), Troubled times: Violence and war in the past. War and society (Vol. 3, pp. 321-356). Amsterdam: Gordon Breach.

Fincher, C. L., Thornhill, R., Murray, D. R., \& Schaller, M. (2008). Pathogen prevalence predicts human cross-cultural variability in individualism/collectivism. Proceedings of the Royal Society of London B, 275, 1279-1285.

Fischer, D. H. (1989). Albion's seed: Four British folkways in America. New York: Oxford University Press.

Fossey, D. (1984). Mountain gorilla research, 1977-1979. National Geographic Society Research Reports, 1976 Projects, 363-412.

Geher, G. (2006). Evolutionary psychology is not evil! (... And here's why...). Psychological Topics, 15, 181-202.

Gerard, H., \& Hoyt, M. F. (1974). Distinctiveness of social categorization and attitude toward in-group members. Journal of Personality and Social Psychology, 29, 836-842.

Ghiglieri, M. P. (1999). The dark side of man: Tracing the origins of male violence. New York: Basic Books.

Goetz, A. T., \& Causey, K. (2009). Sex differences in perceptions of infidelity: Men often assume the worst. Evolutionary Psychology, 7, 253-263.

Goetz, A. T., \& Shackelford, T. K. (2006). Sexual coercion and forced in-pair copulation as sperm competition tactics in humans. Human Nature, 17, 265-282.

Goetz, A. T., Shackelford, T. K., Platek, S. M., Starratt, V. G., \& McKibbin, W. F. (2008). Sperm competition in humans: Implications for male sexual psychology, physiology, anatomy, and behavior. Annual Review of Sex Research, 18, 1-22.

Goetz, A. T., Shackelford, T. K., Romero, G. A., Kaighobadi, F., \& Miner, E. J. (2008). Punishment, proprietariness, and paternity: Men's violence against women from an evolutionary perspective. Aggression and Violent Behavior, 13, 481-489.

Goetz, A. T., Shackelford, T. K., Starratt, V. G., \& McKibbin, W. F. (2008). Intimate partner violence. In J. D. Duntley \& T. K. Shackelford (Eds.), Evolutionary forensic psychology: Darwinian foundations of crime and law (pp. 65-78). New York: Oxford University Press.

Goodall, J. (1979). Life and death at Gombe. National Geographic, 155, 592-621.

Goodall, J. (1986). The chimpanzees of Gombe. Boston: Houghton Mifflin.

Goodman, E. (1999). The role of socioeconomic status gradients in explaining differences in US adolescents' health. American Journal of Public Health, 89, 1522-1528.

Gottschall, J. (2008). The rape of Troy: Evolution, violence, and the world of Homer. Cambridge, MA: Cambridge University Press.

Grinnell, J., Packer, C., \& Pusey, A. (1995). Cooperation in male lions: Kinship, reciprocity or mutualism? Animal Behaviour, 49, 95-105.

Hagen, E. H. (2005). Controversial issues in evolutionary psychology. In D. M. Buss (Ed.), The handbook of evolutionary psychology (pp. 145-173). Hoboken, NJ: Wiley.

Hagen, E. H., Watson, P. J., \& Hammerstein, P. (2008). Gestures of despair and hope: A view on deliberate self-harm from economics and evolutionary biology. Biological Theory, 3, 123-138.

Haley, M. P. (1994). Resource-holding power asymmetries, the prior residence effect, and reproductive payoffs in male northern elephant seal fights. Behavioral Ecology and Sociobiology, 34, 427-434.

Hamilton, W. D. (1964). The genetical evolution of social behaviour, I and II. Journal of Theoretical Biology, 7, 1-52. 
Harris, G. T., Rice, M. E., Hilton, N. Z., Lalumière, M. L., \& Quinsey, V. L. (2007). Coercive and precocious sexuality as a fundamental aspect of psychopathy. Journal of Personality Disorders, 21, 1-29.

Harris, T. R. (2006). Between-group contest competition for food in a highly folivorous population of black and white colobus monkeys (Colobus guereza). Behavioral Ecology and Sociobiology, 61, 317-329.

Hongo, Y. (2003). Appraising behaviour during male-male interaction in the Japanese horned beetle Trypoxylus dichotomus septentrionalis (Kono). Behaviour, 140, 501-517.

Hrdy, S. B. (1977). Infanticide as a primate reproductive strategy. American Scientist, 65, 40-49.

Hrdy, S. B. (1979). Infanticide among animals: A review, classification, and examination of the implications for the reproductive strategies of females. Ethology and Sociobiology, 1, $13-40$.

Hrdy, S. B. (2000). Mother nature: Maternal instincts and how they shape the human species. New York: Ballantine Books.

Janson, C. H., \& van Schaik, C. P. (2000). The behavioral ecology of infanticide by males. In C. P. van Schaik \& C. H. Janson (Eds.), Infanticide in males and its implications (pp. 469-494). Cambridge, MA: Cambridge University Press.

Joiner, T. E., Pettit, J. W., Walker, R. L., Voelz, Z. R., Cruz, J., Rudd, M. D., \& Lester, D. (2002). Perceived burdensomeness and suicidality: Two studies on the suicide notes of those attempting and those completing suicide. Journal of Social and Clinical Psychology, 21, 531-545.

Joiner, T. E., Steer, R. A., Brown, G., Beck, A. T., Pettit, J. W., \& Rudd, M. D. (2003). Worst-point suicidal plans: A dimension of suicidality predictive of past suicidal attempts and eventual death by suicide. Behaviour Research and Therapy, $41,1469-1480$

Kaighobadi, F., \& Shackelford, T. K. (2009). Suspicions of female infidelity predict men's partner-directed violence. Behavioral and Brain Sciences, 32, 281-282.

Keeley, L. H. (1996). War before civilization: The myth of the peaceful savage. New York: Oxford University Press.

Kenrick, D. T., Neuberg, S. L., \& Cialdini, R. B. (2009). Social psychology: Goals in interaction (5th ed.). Boston: Allyn \& Bacon.

Kenrick, D. T., \& Sheets, V. (1993). Homicidal fantasies. Ethology and Sociobiology, 14, 231-246.

Ketelaar, T., \& Ellis, B. J. (2000). Are evolutionary explanations unfalsifiable? Evolutionary psychology and the Lakatosian philosophy of science. Psychological Inquiry, 11, 1-21.

Kruger, D. J. (2010). Socio-demographic factors intensifying male mating competition exacerbate male mortality rates. Evolutionary Psychology, 8, 194-204.

Kruger, D. J., \& Nesse, R. M. (2006). An evolutionary life-history framework for understanding sex differences in human mortality rates. Human Nature, 17, 74-97.

Kruger, D. J., \& Nesse, R. M. (2007). Economic transition, male competition, and sex differences in mortality rates. Evolutionary Psychology, 5, 411-427.

Kurzban, R. (2002). Alas poor evolutionary psychology: Unfairly accused, unjustly condemned. Human Nature Review, 2, 99-109.

Lalumière, M. L., Harris, G. T., Quinsey, V. L., \& Rice, M. E. (2005). The causes of rape: Understanding individual differences in male propensity for sexual aggression. Washington, DC: APA Press.
LeBlanc, S. A. (1999). Prehistoric warfare in the American Southwest. Salt Lake City: University of Utah Press.

Leland, L., Struhsaker, T. T., \& Butynski, T. M. (1984). Infanticide by adult males in three primate species of the Kibale forest, Uganda: A test of hypotheses. In G. Hausfater \& S. Hrdy (Eds.), Infanticide: Comparative and evolutionary perspectives (pp. 151-172). New York: Aldine.

Lester, D. (1991). Questions and answers about murder. Philadelphia: Charles Press.

Letendre, K., Fincher, C. L. \& Thornhill, R. (2010). Does infectious disease cause global variation in the frequency of intrastate armed conflict and civil war? Biological Reviews, 85, 669-683.

Liddle, J. R., Bush, L. S., \& Shackelford, T. K. (2011). An introduction to evolutionary psychology and its application to suicide terrorism. Behavioral Sciences of Terrorism and Political Aggression, 3, 176-197.

Liddle, J. R., \& Shackelford, T. K. (2009). Why evolutionary psychology is "true." A review of Jerry Coyne, Why evolution is true. Evolutionary Psychology, 7, 288-294.

Liddle, J. R., Shackelford, T. K., \& Weekes-Shackelford, V. A. (in press). Why can't we all just get along? Evolutionary perspectives on violence, homicide, and war. Review of General Psychology.

Maynard-Smith, J., \& Price, G. R. (1973). The logic of animal conflict. Nature, 246, 15-18.

McGuffin, P., Marusic, A., \& Farmer, A. (2001). What can psychiatric genetics offer suicidology? Crisis, 22, 61-65.

McKibbin, W. F., \& Shackelford, T. K. (2011). Women's avoidance of rape. Aggression and Violent Behavior, 16, 437-433.

Mech, L. D. (1977). Productivity, mortality, and population trends of wolves in northeastern Minnesota. Journal of Mammalogy, 58, 559-574.

Mech, L. D., Adams, L. G., Meier, T. J., Burch, J. W., \& Dale, B. W. (1998). The wolves of Denali. Minneapolis: University of Minnesota Press.

Mock, D. W. (1984). Infanticide, siblicide, and avian nesting mortality. In G. Hausfater \& S. Hrdy (Eds.), Infanticide: Comparative and evolutionary perspectives (pp. 3-30). New York: Aldine.

Mosser, A., \& Packer, C. (2009). Group territoriality and the benefits of sociality in the African lion, Panthera leo. Animal Behaviour, 78, 359-370.

Motto, J. A., \& Bostrom, A. (1990). Empirical indicators of near-term suicide risk. Crisis, 11, 52-59.

Muller, M. (2007). Chimpanzee violence: Femmes fatales. Current Biology, 17, R365-R366.

Nilsson, D. E., \& Pelger, S. (1994). A pessimistic estimate of the time required for an eye to evolve. Proceedings of the Royal Society of London B, 256, 53-58.

Nisbett, R. E. (1993). Violence and U. S. regional culture. American Psychologist, 48, 441-449.

Norenzayan, A., \& Shariff, A. F. (2008). The origin and evolution of religious prosociality. Science, 322, 58-62.

Öhman, A., \& Mineka, S. (2001). Fears, phobias, and preparedness: Toward an evolved module of fear and fear learning. Psychological Review, 108, 483-522.

Olweus, D. (1978). Aggression in schools. New York: Wiley.

Palmer, C. T., \& Tilly, C. F. (1995). Sexual access to females as a motivation for joining gangs: An evolutionary approach. Journal of Sex Research, 32, 213-217.

Pinker, S. (2009). How the mind works (reissue ed.). New York: W. W. Norton. 
Pusey, A. E., \& Packer, C. (1994). Infanticide in lions: Consequences and counterstrategies. In S. Parmigiani \& F. S. vom Saal (Eds.), Infanticide and parental care (pp. 277-300). Langhorne, PA: Harwood Academic Publishers.

Sanvito, S., Galimberti, F., \& Miller, E. H. (2007). Vocal signaling of male southern elephant seals is honest but imprecise. Animal Behaviour, 73, 287-299.

Schaller, M., Park, J. H., \& Mueller, A. (2003). Fear of the dark: Interactive effects of beliefs about danger and ambient darkness on ethnic stereotypes. Personality and Social Psychology Bulletin, 29, 637-649.

Sear, R., \& Mace, R. (2008). Who keeps children alive? A review of the effects of kin on child survival. Evolution and Human Behavior, 29, 1-18.

Sell, A., Hagen, E., Cosmides, L., \& Tooby, J. (2003). Evolutionary psychology: Applications and criticisms. In Encyclopedia of cognitive science (pp. 47-53). London: Macmillan.

Shackelford, T. K. (2005). An evolutionary psychological perspective on cultures of honor. Evolutionary Psychology, 3, 381-391.

Simmons, R. (2002). Odd girl out: The hidden culture of aggression in girls. London: Harcourt.

Smith, D. L. (2007). The most dangerous animal. Human nature and the origins of war. New York: St. Martin's.

Stearns, S. C. (1992). The evolution of life histories. Oxford, England: Oxford University Press.

Straus, M., Gelles, R. J., \& Steinmetz, S. K. (2006). Behind closed doors: Violence in the American family. Piscataway, NJ: Transaction Publishers.

Sulloway, F. J. (1996). Born to rebel. New York: Pantheon.

Thornhill, R., Fincher, C. L., \& Aran, D. (2009). Parasites, democratization, and the liberalization of values across contemporary countries. Biological Reviews, 184, 113-131.

Thornhill, R., Fincher, C. L., Murray, D. R. \& Schaller, M. (2010). Zoonotic and non-zoonotic diseases in relation to human personality and societal values: Support for the parasite-stress model. Evolutionary Psychology, 8, 151-169.

Thornhill, R., \& Palmer, C. T. (2000). A natural history of rape. Cambridge, MA: MIT Press.

Tooby, J., \& Cosmides, L. (1988). The evolution of war and its cognitive foundations. Institute for Evolutionary Studies Technical Report \#88-1. Retrieved November 2011, from http://www.psych.ucsb.edu/research/cep/papers/Evolofwar. pdf
Tooby, J., \& Cosmides, L. (2005). Conceptual foundations of evolutionary psychology. In D. M. Buss (Ed.), The handbook of evolutionary psychology (pp. 5-67). Hoboken, NJ: Wiley.

Trivers, R. L. (1972). Parental investment and sexual selection. In B. Campbell (Ed.), Sexual selection and the descent of man 1871-1971 (pp. 136-179). Chicago: Aldine.

Twain, M. (1992). Man's place in the animal world. In L. J. Budd (Ed.), Mark Twain: Collected tales, sketches, speeches, and essays. Volume 2: 1891-1910 (pp. 207-216). New York: Literary Classics of the United States. (Original work published 1896)

Underwood, R. C., \& Patch, P. C. (1999). Siblicide: A descriptive analysis of sibling homicide. Homicide Studies, 3, 333-348.

US Department of Justice, Federal Bureau of Investigation, Criminal Justice Information Services Division. (2010, September). Crime in the United States, 2009. Retrieved June 2011, from http://www2.fbi.gov/ucr/cius2009/index. $\mathrm{html}$

Vaillancourt, T., Hymel, S., \& McDougall, P. (2003). Bullying is power: Implications for school-based intervention strategies. Journal of Applied School Psychology, 19, 157-176.

van der Dennen, J. M. G. (1995). The origin of war: The evolution of a male-coalitional reproductive strategy. Gronigen, The Netherlands: Origin Press.

Wakefield, J. C. (1992). The concept of mental disorder: On the boundary between biological facts and social values. American Psychologist, 47, 373-388.

Waterman, J. (1984). Infanticide in the Columbian ground squirrel, Spermophilus columbianus. Journal of Mammalogy, 65, 137-138.

Watson, P. J., \& Andrews, P. W. (2002). Toward a revised evolutionary adaptationist analysis of depression: The social navigation hypothesis. Journal of Affective Disorders, 72, 1-14.

Wiehe, V. R. (1997). Sibling abuse. Thousand Oaks, CA: Sage Publications.

Wilson, M., \& Daly, M. (1992). The man who mistook his wife for a chattel. In J. H. Barkow, L. Cosmides, \& J. Tooby (Eds.), The adapted mind (pp. 289-322). New York: Oxford University Press.

World Health Organization. (2010). Suicide prevention. Retrieved June 2011, from http://www.who.int/mental_health/prevention/suicide/suicideprevent/en/index.html

Zahavi, A., \& Zahavi, A. (1996). The handicap principle. New York: Oxford University Press. 